JURNAL CERIA

ISSN : 2614-6347 (Print) 2714-4107 (Online)

Vol.2 | No.6 | November 2019

\title{
MENGEMBANGKAN KECERDASAN LOGIS MATEMATIK PADA ANAK USIA DINI MELALUI METODE CERITA BERGAMBAR MODEL POP UP KELOMPOK B
}

\author{
Desy Eka Putri ${ }^{1}, S_{i t i}$ Nurinayah $^{2}$, Fifiet Dwi Tresna Santana ${ }^{3}$, Dewi Safitri Elsap ${ }^{4}$ \\ ${ }^{1}$ IKIP Siliwangi, Jl. Terusan Jendral Sudirman, Cimahi \\ ${ }^{2}$ IKIP Siliwangi, Jl. Terusan Jendral Sudirman, Cimahi \\ ${ }^{3}$ IKIP Siliwangi, Jl. Terusan Jendral Sudirman, Cimahi \\ ${ }^{4}$ IKIP Siliwangi, Jl. Terusan Jendral Sudirman, Cimahi \\ 1-desyekaputri48@gmail.com, 2. sitinurinayah357@gmail.com, \\ 느shap@stkipsiliwangi.ac.id
}

\begin{abstract}
ABTRACT
This research was conducted to find out the differences from the learning methods of ordinary pictorial stories with the pop up models of the more unique and different pop up models, but also through this research it is hoped to provide new experiences for children, bearing in mind that learning is still focused on writing, reading and counting (calistung). This study uses the experimental method because there is a comparison between the control class and the experimental class. The subject and location of the study were group B students. The study population was the B-Saturn group and the B-Uranus group with a sample students, with a total of 28 students. Data collection techniques using pretest and posttest. Pretest technique using ordinary picture stories while in the posttest technique using picture models pop up. Results of Research The average value (mean) in the control class is BB (1.21), MB (0.21), BSB (0.42) and BSH (0.14) while in the experimental class the average value is BB (0.29), MB (0.21), BSB (0.5) and BSH (0.14). Then it can be concluded that "Hypothesis is accepted", meaning that there is a difference between student learning outcomes to develop mathematical logical intelligence in the pretest and post test. So that it can be concluded mathematical logical intelligence by using the pop up model pictorial story method is better than groups that use ordinary learning.
\end{abstract}

Keyword : Mathematical Logical Intellegence, Story Method, Story Book Model Pop Up

\begin{abstract}
ABSTRAK
Tujuan penelitian ini dilakukan untuk mengetahui perbedaan dari pembelajaran metode cerita bergambar biasa dengan metode cerita bergambar model pop up yang lebih unik dan berbeda, selain itu juga melalui penelitian ini diharapkan memberikan pengalaman yang baru bagi anak, mengingat pembelajaran yang masih terfokus pada menulis, membaca dan berhitung (calistung). Penelitian ini menggunakan metode eksperimen sebab ada perbandingan antara kelas kontrol dan kelas eksperimen. Subjek adalah peserta didik kelompok B. Populasi penelitian ini adalah kelompok B-Saturnus dan kelompok B-Uranus dengan sampel peserta didik yang berjumlah 28 peserta didik. Tekhnik pengumpulan data dengan menggunakan pretest dan postest. Teknik pretest dengan menggunakan cerita bergambar biasa sedangkan dalam tekhnik postest dengan menggunakan cerita bergambar model pop up. Hasil Penelitian nilai rata-rata (mean) pada kelas kontrol adalah BB (1.21), MB (0.21), BSB (0.42) dan BSH (0.14) sedangkan pada kelas eksperimen nilai rata-rata adalah BB (0.29), MB (0.21), BSB (0.5) dan BSH (0.14). Maka dapat
\end{abstract}




\section{JURNAL CERIA}

ISSN : 2614-6347 (Print) 2714-4107 (Online)

Vol.2 | No.6 | November 2019

disimpulkan bahwa "Hipotesis diterima", artinya ada perbedaan antara hasil belajar peserta didik untuk mengembangkan kecerdasan Logis Matematik dalam pretest dan post test. Sehingga dapat disimpulkan kecerdasan logis matematik dengan melalui metode cerita bergambar model pop up lebih baik dari kelompok yang menggunakan pembelajaran biasa.

Kata kunci : Kecerdasan Logis Matematik, Metode Cerita, Buku Cerita Model Pop Up

\section{PENDAHULUAN}

Mengenai PAUD ini, menurut UU No.20 Tahun 2003 tentang Sistem Pendidikan Nasional Bab 1, pasal 1, butir 14 dinyatakan bahwa "Pendidikan Anak Usia Dini adalah suatu upaya pembinaan yang ditujukan kepada anak sejak lahir sampai dengan usia enam tahun yang dilakukan melalui pemberian rangsangan pendidikan untuk membantu pertumbuhan dan perkembangan jasmani dan rohani agar anak memiliki kesiapan dalam memasuki pendidikan lebih lanjut." Pendidikan AUD hakikat dasarnya ialah salah satu jalur pendidikan yang memberikan fasilitas untuk perkembangan dan pertumbuhan pada anak. Dimana pendidikan ini memotivasi potensi dari setiap anak yang berbeda, mengerti tentang karakteristik AUD serta mengembangkan aspek-asek yang harus dipenuhi, seperti aspek perkembangan nilai moral dan agama, aspek perkembangan sosial emosional, aspek perkembangan kognitif, aspek perkembangan motorik kasar dan halus, dan aspek perkembangan seni. Pendidikan AUD sangatlah penting sebab melalui jalur pendidikan ini anak mampu berkembang sesuai usianya serta pembelajarannya pun terarah tanpa mengubah karakteristiknya sebab anak usia dini belajar melalui bermain. Selain itu masa ini juga termasuk masa dimana anak peka terhadap rangsangan.
Tujuan PAUD ialah memberikan rangsangan terhadap perkembangan AUD (0-6 tahun). Sehingga melalui rangsangan tersebut, dapat mengembangkan setiap aspek-aspek perkembangan dan juga kecerdasannya. Selain itu, tujuan utama PAUD adalah untuk membentuk generasi yang memiliki kualitas, yaitu terstimulasi tumbuh kembangnya sesuai dengan tingkatan usianya yang berbeda serta memiliki kesiapan yang matang di dalam memasuki pendidikan dasar dan juga memiliki kesiapan dalam mengarungi kehidupan pada masa yang akan datang. Kemudian tujuan lainnya dari PAUD adalah membantu mempersiapkan anak dalam belajar pada jenjang berikutnya sehingga nantinya dapat mengurangi usia berhenti sekolah serta mampu bersaing dengan sehat dalam pendidikan berikutnya.

Dalam dunia PAUD selain aspek perkembangan adapula tentang kecerdasan majemuk. Kecerdasan ini sering kita kenal dengan Teori Multiple Intellegence dikemukakan Howard Gardner meliputi kecerdasan linguistik/bahasa, kecerdasan logis-matematik, kecerdasan musikal, kecerdasan spasial-visual, kecerdasan kinestetik-jasmani, serta kecerdasan intrapersonal, kecerdasan intrapersonal juga kecerdasan naturalis. biasanya kecerdasan majemuk tidak mendapatkan penilaian atau evaluasi di sekolah. Sebab di lembaga formal hanya 


\section{JURNAL CERIA}

ISSN : 2614-6347 (Print) 2714-4107 (Online)

Vol.2 | No.6 | November 2019

menjadikan dua-tiga kecerdasan yang diakui sebagai tolak ukur keberhasilan atau prestasi anak itupun yang berhubungan dengan matematika atau perkembangan kognitif dan juga aspek bahasa (linguistik), Padahal sejatinya setiap multiple intelegence AUD dapat di kembangkan sesuai dengan potensi anak.

Salah satu kecerdasan yang perlu dikembangkan adalah kecerdasan logika-matematika (logis-matematis), sebab kecerdasan tersebut dapat menjadi penunjang dalam aspek kawasan kognitif bagi PAUD. Aspek perkembangan kognitif adalah salah satu aspek perkembangan yang di stimulasi melalui pengenalan bilangan dan permainan angka. Aspek ini juga sangat penting untuk dikembangkan terlebih pada anak yang senang dengan bilangan. Pernyataan ini tidak jauh beda dengan salah satu kecerdasan majemuk yaitu Kecerdasan logika-matematika. Kecerdasan logika matematika (logis-matematis) adalah kecerdasan dalam hal angka, hal-hal yang berhubungan dengan bilangan, membuat hipotesis, berpikir dalam konsep sebab akibat, dan pola untuk konsep-konsep. Orang-orang yang kecerdasan utamanya berupa kecerdasan logika sangat pintar dan mahir dalam berhitung, menarik hipotesis, komputasi, bekerja dengan menggunakan komputer atau membuat program komputer, menggunakan statistik, menalar, membuat estimasi, audit, akuntansi, membuat sistem, melakukan penelitian, bekerja menggunakan teori ekonomi, dan hal-hal yang berkaitan dengan angka. Maka dari itulah aspek kognitif dan kecerdasan logis matematik saling berkaitan satu sama lain.

Metode dalam penelitian ini adalah untuk mengembangkan kecerdasan logis matematik ini adalah metode cerita dengan menggunakan media pembelajaran cerita bergambar model pop up. Karena salah satu karakteristik AUD adalah suka berfantasi dan berimajinasi serta memiliki daya konsentrasi yang pendek. Metode cerita menjadi salah satu metode untuk meningkatkan sifat imajinasi anak, dan cerita bergambar model pop up merupakan sebuah media pembelajaran yang unik dalam suatu proses kegiatan yang menggunakan metode cerita. Dimana buku cerita tersebut berbentuk semi 3 D sehingga terlihat unik bagi AUD, melalui keunikannya lah diharapkan buku cerita model pop up ini dapat meningkatkan konsentrasi anak sehingga mampu memusatkan perhatiannya. Selain itu melalui metode ini pula diharapkan dapat menstimulasi anak dalam mengenal angka, warna, konsep persamaan dan konsep perbedaan, serta mengkelompokkan benda berdasarkan warna dan bentuk sesuai dengan media cerita bergambar model pop up. Sedangkan manfaat media Pop-Up Book sendiri menurut Dewanti, Toenlioe \& Supriyanto (2018) antara lain: (1) Mengajarkan anak untuk menghargai buku dan merawatnya dengan baik, (2) Mengembangkan kreatifitas anak, (3) Merangsang imajinasi anak, (4) Memberi pengetahuan serta (5) Dapat digunakan sebagai media untuk menumbuhkan motivasi baca pada anak.

Rumusan masalah dalam penelitian ini adalah apakah dengan metode cerita bergambar model pop up pada AUD dapat mengembangkan kecerdasaan logis-matematik kelompok B di TK As-Salaam?. Dengan tujuan penelitian untuk mengetahui sejauh mana metode cerita bergambar model pop up dapat mengembangkan 


\section{JURNAL CERIA}

ISSN : 2614-6347 (Print) 2714-4107 (Online)

Vol.2 | No.6 | November 2019

kecerdasaan logis-matematik pada anak usia dini kelompok B TK As-Salaam.

\section{METODE PENELITIAN}

Metode penelitian yang digunakan dalam penelitian ini adalah metode eksperimen. Metode penelitian eksperimen digunakan karena gejala yang ditimbulkan diperlukan sengaja oleh peneliti. Prnrlitian ini menggunakan bentuk desain yaitu pre-eksperimen desain, yaitu one group pretest-posttest design. Metode penelitian eksperimen selalu dilakukan dengan maksud untuk melihat sebab akibat perlakuan (Arikunto, 2010).

Menurut Sugiyono (2008)

"Metode penelitian eksperimen ini diartikan sebagai metode penelitian yang menggunakan pengaruh untuk mencari perlakuan tertentu terhadap kondisi yang terkendali”. Peneliti ingin mendeskripsikan apakah metode cerita bergambar model pop up pada AUD dapat mengembangkan kecerdasan logis matematik kelompok $\mathrm{B}$ di TK As-Salaam?.

Penelitian ini dilakukan pada waktu 3 bulan dimulai pada bulan Maret-Mei 2019. Menurut para ahli Populasi penelitian adalah wilayah generalisasi yang terdiri atas objek atau subjek yang mempunyai kualitas dan karakteristik tertentu yang ditetapkan oleh peneliti untuk dipelajari dan kemuadian ditarik kesimpulannya (Sugiyono, 2008:90). Yang menjadi pepulasi dalam penelitian ini adalah peserta didik kelompok $\mathrm{B}$ di TK As-Salaam yang berjumlah 28 anak.

Tekhnik pengumpulan yang digunakan adalah tekhnik berupa dokumentasi, evaluasi dan observasi. Tes adalah evaluasi dari pertanyaan-pertanyaan yang diberikan kepada anak untuk mendapat jawaban dari anak dalam bentuk lisan maupun dalam bentuk perbuatan. Dalam PAUD sebaiknya tes tidak berupa tulisan sebab tes tertulis bagi anak akan membuat anak stress dan mudah bosan. Tes bisa diganti dengan observasi, pendokumentasian dan proses dalam menghasilkan karya bagi anak.

\section{HASIL DAN PEMBAHASAN Hasil}

Data penelitian hasil observasi yang telah dilakukan pada kelompok B di TK As-Salaam pada cerita bergambar dengan media buku cerita model pop up.

Data-data penelitian ditabulasikan ke dalam tabel dan hasilnya sebagai berikut :

Tabel 1

Data kelas kontrol

\begin{tabular}{|c|c|c|c|c|c|}
\hline \multirow{2}{*}{$\begin{array}{l}\text { Kls } \\
\text { kontr } \\
\text { ol }\end{array}$} & \multirow{2}{*}{$\begin{array}{l}\mathrm{N} . \\
\text { Statis } \\
\text { tic }\end{array}$} & \multicolumn{4}{|c|}{ Penilaian } \\
\hline & & $\begin{array}{l}\text { B } \\
\text { B }\end{array}$ & $\begin{array}{l}\mathrm{M} \\
\mathrm{B}\end{array}$ & $\begin{array}{c}\mathrm{BS} \\
\mathrm{B}\end{array}$ & $\begin{array}{c}\text { BS } \\
\mathrm{H}\end{array}$ \\
\hline $\begin{array}{l}\text { prete } \\
\text { st }\end{array}$ & 14 & 9 & 1 & 4 & - \\
\hline $\begin{array}{l}\text { Post } \\
\text { test }\end{array}$ & 14 & 8 & 2 & 2 & 2 \\
\hline & $\sum$ & 17 & 3 & 6 & 2 \\
\hline & mean & $\begin{array}{c}1.2 \\
1 \\
\end{array}$ & $\begin{array}{c}0.2 \\
1 \\
\end{array}$ & $\begin{array}{c}0.4 \\
2 \\
\end{array}$ & $\begin{array}{c}0.1 \\
4 \\
\end{array}$ \\
\hline
\end{tabular}

Tabel 2

Data kelas eksperimen

\begin{tabular}{|c|c|c|c|c|c|}
\hline \multirow{2}{*}{$\begin{array}{l}\text { Kls } \\
\text { kontr } \\
\text { ol }\end{array}$} & \multirow{2}{*}{$\begin{array}{l}\mathrm{N} . \\
\text { Statis } \\
\text { tic }\end{array}$} & \multicolumn{4}{|c|}{ Penilaian } \\
\hline & & $\begin{array}{l}B \\
B\end{array}$ & $\begin{array}{l}\mathrm{M} \\
\mathrm{B}\end{array}$ & $\begin{array}{c}\text { BS } \\
\text { B }\end{array}$ & $\begin{array}{c}\text { BS } \\
\mathrm{H}\end{array}$ \\
\hline $\begin{array}{l}\text { prete } \\
\text { st }\end{array}$ & 14 & 3 & 2 & 3 & 6 \\
\hline $\begin{array}{l}\text { Post } \\
\text { test }\end{array}$ & 14 & 1 & 3 & 4 & 6 \\
\hline
\end{tabular}




\section{JURNAL CERIA}

ISSN : 2614-6347 (Print) 2714-4107 (Online)

Vol.2 | No.6 | November 2019

\begin{tabular}{|c|c|c|c|c|c|}
\hline & $\sum$ & 4 & 5 & 7 & 12 \\
\hline & mean & $\begin{array}{c}0.2 \\
9\end{array}$ & $\begin{array}{c}0.3 \\
5\end{array}$ & 0.5 & $\begin{array}{c}0.8 \\
5\end{array}$ \\
\hline
\end{tabular}

Dari hasil tabel di atas

dinyatakan bahwa nilai rata-rata (mean) pada kelas kontrol adalah BB (1.21), MB (0.21), BSB (0.42) dan BSH (0.14) sedangkan pada kelas eksperimen nilai rata-rata adalah $\mathrm{BB}(0.29), \mathrm{MB}(0.21)$, BSB (0.5) dan BSH (0.14). Hasil rata-rata perkembangan antara kelas kontrol dan kelas eksperimen tersebut ditarik kesimpulan bahwa kecerdasan logis matematik anak mengalami perkembangan yang signifikan pada kelas eksperimen dilihat dari penilaian BB (Belum Berkembang) lebih sedikit dan BSH (Berkembang Sesuai Harapan) yang lebih besar daripada kelas kontrol.

Maka kesimpulannya adalah "Hipotesis diterima", artinya ada perbedaan antara hasil belajar anak dalam mengembangkan kecerdasan Logis Matematik dalam pretest dan post test. Sehingga dapat disimpulkan demikian "ada pengaruh dalam pengembangan kecerdasan logis matematik pada Anak Usia Dini melalui metode cerita bergambar model pop up di kelompok B"

\section{Pembahasan}

Media buku cerita bergambar model pop up sebagai media bantu dalam mengembangkan kecerdasan logis matematik pada Anak Usia Dini karena media ini menjadi media pembelajaran yang memotivasi anak sehingga dapat mempermudah anak dalam mengenal angka, warna, dan bentuk serta memecahkan masalah sederhana dengan model yang unik semi 3 D. Selain itu media ini juga dapat digunakan sebagai media untuk meningkatkan daya nalar serta konsentrasi anak. Dimana anak akan merasa senang, nyaman, serta penuh tantangan dalam mengikuti pembelajaran.

\section{KESIMPULAN}

Maka dapat ditarik kesimpulan bahwa Tujuan Pendidikan Anak Usia Dini ialah jalur pendidikan yang menstimulasi anak dalam mengembangkan berbagai potensi yang ada pada dirinya. Dimana potensi setiap anak itu unik dan berbeda. Cerita bergambar model pop up merupakan sebuat media yang unik dalam setiap proses pembelajaran. dimana buku cerita tersebut berbentuk semi 3 D sehingga terlihat unik bagi anak usia dini, melalui keunikannya lah diharapkan buku cerita model pop up ini dapat meningkatkan pula daya konsentrasi anak sehingga mampu memusatkan perhatiannya. kecerdasan intrapersonal, kecerdasan intrapersonal, kecerdasan naturalis. Sehingga peneliti mendapat kesimpulan demikian pengembangan kecerdasan logis matematik pada Anak Usia Dini melalui metode cerita bergambar model pop up di Kelompok B TK As-Salaam lebih baik dari pembelajaran yang biasa.

\section{DAFTAR PUSTAKA}

Arikunto, S. (2010) Prosedur Penelitian Suatu Pendekatan Praktik. Jakarta Rineka Cipta.

Dewanti, H., Toenlioe, A. J.E., \& Soepriyanto, Y. (2018). Pengembangan Media Popo Up Book untuk Pembelajaran Lingkungan Tempat Tinggalku Kelas IV SDN 1 Pakunden Kabupaten Ponorogo. Jurnal Kajian Teknologi Pendidikan. 1(3), pp. 221-228. 


\section{JURNAL CERIA}

ISSN : 2614-6347 (Print) 2714-4107 (Online)

Vol.2 | No.6 | November 2019

Sugiyono. 2008. Metode Penelitian

UU No 20 Tahun 2003 tentang Sistem

Kuantitatif Kualitatif dan R\&D.

Pendidikan Nasional

Bandung : ALFABETA 